\title{
Development of New Composite Products Based on Flax Fibres
}

\author{
Daniela-Roxana Tămaş-Gavrea ${ }^{1, *}$, Raluca Iștoan ${ }^{1}$, Ancuţa Elena Tiuc ${ }^{2}$ (D) Tünde-Orsolya Dénes ${ }^{1}$, \\ Ovidiu Vasile ${ }^{3}$ (D) and Horia Constantinescu ${ }^{1}$ (1)
}

1 Department of Civil Engineering and Management, Technical University of Cluj-Napoca, 400114 Cluj-Napoca, Romania; ralucafernea@ccm.utcluj.ro (R.I.); orsolya.denes@ccm.utcluj.ro (T.-O.D.); Horia.Constantinescu@dst.utcluj.ro (H.C.)

2 Department of Environmental Engineering and Sustainable Development Entrepreneurship, Technical University of Cluj-Napoca, 400641 Cluj-Napoca, Romania; ancuta.tiuc@imadd.utcluj.ro

3 Department of Mechanics, University Politehnica of Bucharest, 060042 Bucharest, Romania; ovidiu_vasile2002@yahoo.co.uk

* Correspondence: roxana.tamas@ccm.utcluj.ro

Citation: Tămaş-Gavrea, D.-R.; Iştoan, R.; Tiuc, A.E.; Dénes, T.-O.; Vasile, O.; Constantinescu, $\mathrm{H}$. Development of New Composite Products Based on Flax Fibres.

Coatings 2021, 11, 551.

https://doi.org/10.3390/ coatings11050551

Academic Editor: Maryam Naebe

Received: 6 April 2021

Accepted: 3 May 2021

Published: 7 May 2021

Publisher's Note: MDPI stays neutral with regard to jurisdictional claims in published maps and institutional affiliations.

Copyright: (c) 2021 by the authors. Licensee MDPI, Basel, Switzerland. This article is an open access article distributed under the terms and conditions of the Creative Commons Attribution (CC BY) license (https:// creativecommons.org/licenses/by/ $4.0 /)$.
Abstract: Plant fibres are materials that can increase energy savings, and they are being analysed for their reduced environmental impact. In this paper, three types of multi-layered panels were developed as environmentally friendly flax fibre-based products for building industry applications. The structural build-up of the panels is such that one layer of waste flax fibre was used as the core material in order to reduce the weight of the structure between two rigid perlite-based layers. The perlite was used in three varied grain sizes, resulting in three types of panels $\left(\mathrm{S}_{1}, \mathrm{~S}_{2}, \mathrm{~S}_{3}\right)$. The mechanical, thermal and acoustic properties were recorded for all specimens. The influence of the perlite particles' size, perforation diameter and perforation percentage of the multi-layered panels on the acoustic absorption properties was analysed and discussed. Summarising the results, the multi-layered composite panel $S_{3}$ presented the best performance in regard to compressive strength and thermal conductivity, with $S_{2}$ presenting the best bending strength. From the acoustic point of view, for the unperforated panels, the highest values of the sound absorption coefficient were obtained at $500 \mathrm{~Hz}$ for $\mathrm{S}_{1}, \alpha=0.95,315 \mathrm{~Hz}$ for $\mathrm{S}_{2}, \alpha=0.89$ and $400 \mathrm{~Hz}$ for $\mathrm{S}_{3}, \alpha=0.84$. The obtained values of the sound absorption coefficients were increased through the varied perforation diameters and percentages of the panels' front face.

Keywords: composite panels; flax fibres; perlite; mechanical properties; thermal properties; acoustic properties

\section{Introduction}

In recent decades, as urbanisation has increased, finding the raw materials and energy to produce building materials and absorbing the emitted waste from their production, use and disposal have become important global problems that may affect everyone around the planet [1]. The increased awareness of environmental issues has motivated researchers and manufacturers to seek the constant improvement of composite and bio-composite material production [2], with the aim of displacing or reducing the existing glass fibrebased composites or polymers, which are expensive to produce and are generally based on petrochemicals [3]. An excellent way to manage the use of this existing resource is the development of agricultural biomass-based composites [4]. Among different types of materials, natural cellulosic fibres possess a number of advantages, such as: all plant-derived fibres absorb carbon dioxide during their growth [5], they have a lower environmental impact compared to glass fibres production [6], and they are cheap [7], eco-friendly and renewable [8,9]. Until now, plant-based fibres have not been comprehensively studied, and their utilisation for the production of industrial composites is still under development in many respects [10]. The current legislation and the increasing awareness of alternative materials, which can provide insulating properties, have led to the development of new 
materials, an opportunity for a sustainable environment [11]. Additionally, nowadays, the agricultural sector is growing rapidly due to the new research and development of technologies that help the agricultural process [12].

In the Report of the World Commission on Environment and Development: Our common future [13], sustainable development "meets the needs of the present without compromising the ability of future generations to meet their own needs", the objective of this research being the realisation of new alternative materials based on natural fibres to fulfil this definition.

In recent years, natural fibres, which can be of various origins such as vegetable (cotton, kenaf, hemp, flax, wood, etc.), animal (wool, fur felt) or mineral (asbestos) [14], have been used in the development of new thermal and sound absorption structures. However, most builders are uncertain whether the alternative materials reach the same performance measures as conventional building materials, with the supporting scientific information being difficult to find [15].

From the naturally available fibres, flax fibres have been widely used in the industry, being applied in a number of practical applications, for example affecting the mechanical, thermal and acoustic properties of fibrous porous media [16,17].

Flax has good mechanical properties compared with other natural fibres [18] and rates highest among natural fibres in terms of tensile strength, a property critical to the behaviour of a crack inhibitor in a cementitious composite [19]. Furthermore, flax fibre embedded in an epoxy-matrix showed significantly higher damping of vibrations at lower densities [20].

In terms of acoustic and thermal performances, the insulation materials based on natural fibres are suitable for use in civil engineering [21]. A thermal conductivity coefficient of $0.085 \mathrm{~W} / \mathrm{mK}$ was obtained by Babenko et al. [22] in a study based on flax straw, making it an effective insulation material for sustainable buildings.

The sound absorption properties of natural fibres (ramie, jute and flax) and their reinforced composite were found to be superior to those of synthetic fibres (glass and carbon fibre) and their reinforced composite in the research by Yang and Li [23].

Although noise protection is one of the essential requirements provided by the Council Directive 89/106/CEE [24], according to our previous research works [25], this issue is often neglected.

In this research, the acoustic quality and comfort, both of which are key considerations in a sustainably built environment [26], were considered through a thorough investigation of the sound absorption properties of three new multi-layered composite panels based on flax fibres.

Therefore, in this research, a link between acoustic comfort and urban development, with implications for producing new natural-based products comparable with the synthetic ones needed for a well-designed sound environment, was realised.

\section{Materials and Methods}

\subsection{Materials}

Three types of multi-layered composite panels were fabricated using two rigid perlitebased sheets reinforced with a natural flax fibre net, between which a core comprising flax fibres with lengths ranging between 200 and $300 \mathrm{~mm}$ was used as a filler. The panels were $300 \mathrm{~mm}$ long, $300 \mathrm{~mm}$ wide and $50 \mathrm{~mm}$ thick.

The recipe used in the rigid sheet manufacturing process was composed of perlite, white cement, lime and water, while for the panel core fabrication process, flax fibre and a binder made of white cement and water in equal quantities were used [27].

All specimens share the same structure, but the expanded perlite aggregates, supplied by "Procema Perlit SRL" (Jilava, Romania), were used in different particle sizes, resulting in three types of panels $\left(S_{1}, S_{2}, S_{3}\right)$, as shown in Table 1. 
Table 1. Expanded perlite types.

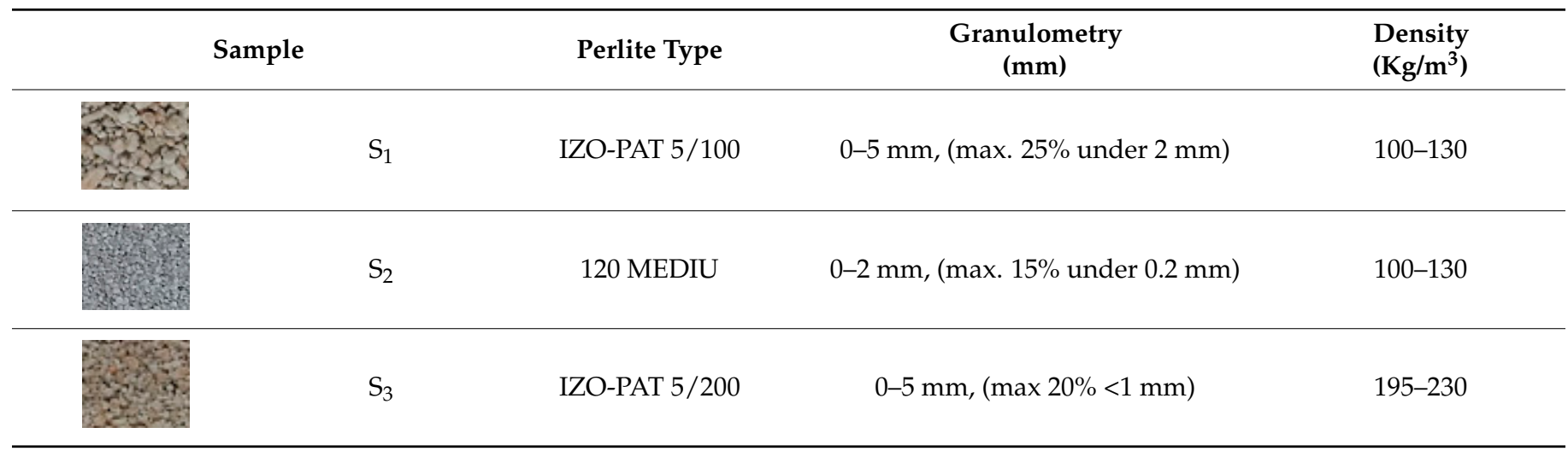

\subsection{Methods}

The multi-layered composite panels were made under laboratory conditions, using the following instructions. A wooden mould of $300 \times 300 \mathrm{~mm}^{2}$ was used to create the rigid sheets of the panel. The $5 \mathrm{~mm}$ face sheets were manufactured by mixing, in a plastic container, the required quantities of perlite, white cement and lime over which water was gradually added and mixed until homogenous. Initially, one-quarter of the measured quantity of the mixture was poured into the wooden mould and uniformly compressed. A wet, natural flax fibre net was placed into the mould, over which an identical amount of mixture was poured and evenly compacted. A cement-based binder was spread by a spray paint gun over the flax fibres, which were arranged in the wooden mould. The second sheet, manufactured following the same procedure as in the first case, was applied over the flax fibre [27]. After $24 \mathrm{~h}$, the panel was extracted from the mould and stored according to the regulations in force, including 28 days of maturation. Three types of multi-layered composite panels, with perlite in different particles sizes, were fabricated (Figure 1).
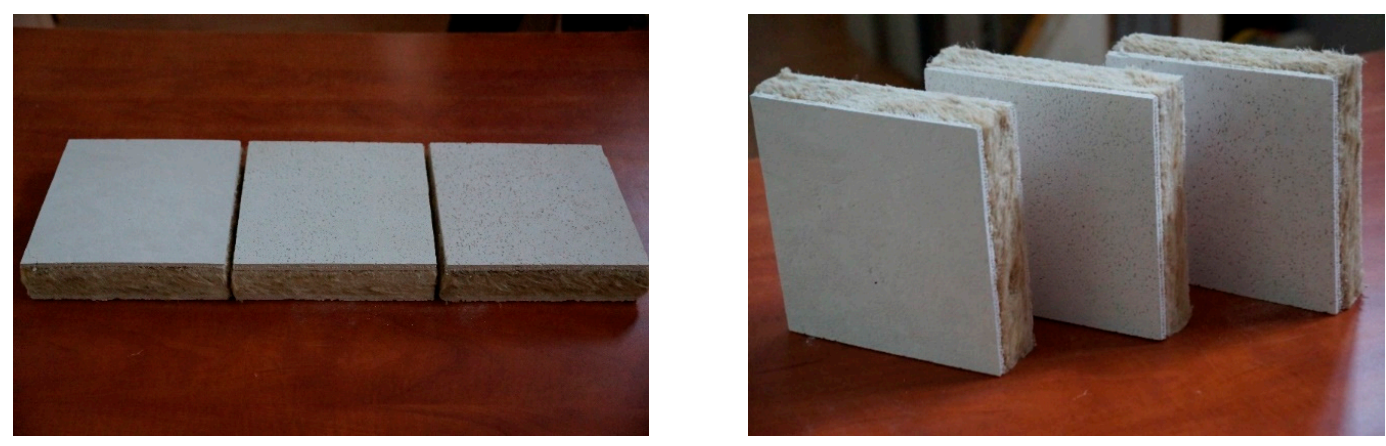

Figure 1. Multi-layered composite panels with perlite in different particles sizes: from right to left, “izo-pat 5/100" perlite sample $\left(S_{1}\right)$, “120 mediu" perlite sample $\left(S_{2}\right)$, “izo-pat $5 / 200$ ” perlite sample $\left(S_{3}\right)$.

In order to analyse the influence of the perlite type on the mechanical properties of the samples, bending and compression tests were developed respecting the SR EN 12089:2013 [28] and SR EN 826:2013 [29] prescriptions. From each type of panel, samples with the dimensions of $300 \times 150 \times 50 \mathrm{~mm}^{3}$ for bending and of $100 \times 100 \times 50 \mathrm{~mm}^{3}$ for compression were subjected to mechanical determinations. The tests were carried out with the universal test equipment ZDM-5/91, at a temperature above $23^{\circ} \mathrm{C}$ and a relative humidity of $45 \%$.

The thermal performances of the samples, according to the perlite type, were analysed considering the SR EN 12664:2002 [30] recommendations, using the instrument FOX 200 for thermal conductivity determinations. The tests were performed on samples with the 
dimensions of $150 \times 150 \times 50 \mathrm{~mm}^{3}$ when the differences of the sample's masses between two successive weightings did not register as more than $0.1 \mathrm{~g}$.

The obtained panels were also subjected to acoustic determinations by considering the SR EN ISO 10534-2:2002 [31] recommendations. A number of 18 cylindrical specimens with a diameter of $63.5 \mathrm{~mm}$ (Figure 2) were evaluated by using an impedance tube. Comparative analysis was developed by considering the perlite particles' size, perforation diameter and perforation percentage.

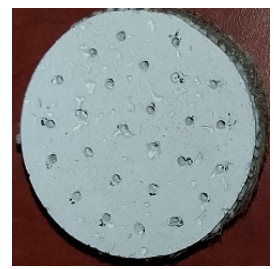

$\mathrm{S}_{1}, \mathrm{~d}=2 \mathrm{~mm}, \mathrm{p}=2.5 \%$

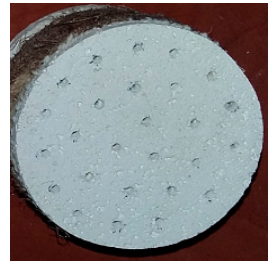

$\mathrm{S}_{2}, \mathrm{~d}=2 \mathrm{~mm}, \mathrm{p}=2.5 \%$

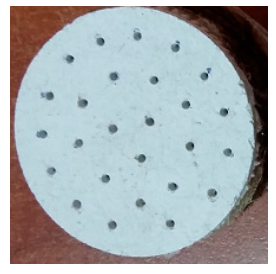

$\mathrm{S}_{3}, \mathrm{~d}=2 \mathrm{~mm}, \mathrm{p}=2.5 \%$

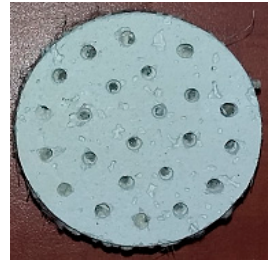

$\mathrm{S}_{1}, \mathrm{~d}=3 \mathrm{~mm}, \mathrm{p}=5 \%$

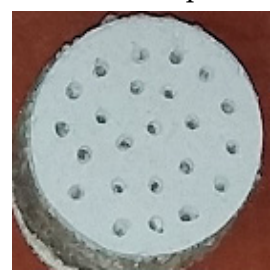

$\mathrm{S}_{2}, \mathrm{~d}=3 \mathrm{~mm}, \mathrm{p}=5 \%$

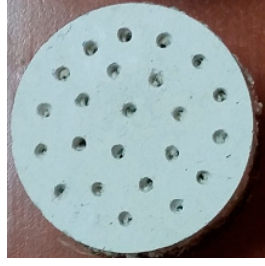

$\mathrm{S}_{3}, \mathrm{~d}=3 \mathrm{~mm}, \mathrm{p}=5 \%$

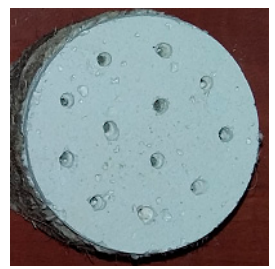

$\mathrm{S}_{1}, \mathrm{~d}=3 \mathrm{~mm}, \mathrm{p}=2.5 \%$

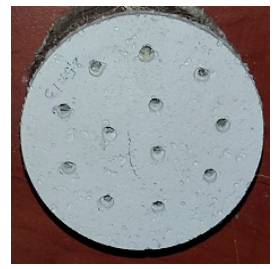

$\mathrm{S}_{2}, \mathrm{~d}=3 \mathrm{~mm}, \mathrm{p}=2.5 \%$

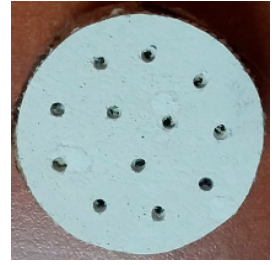

$\mathrm{S}_{3}, \mathrm{~d}=3 \mathrm{~mm}, \mathrm{p}=2.5 \%$

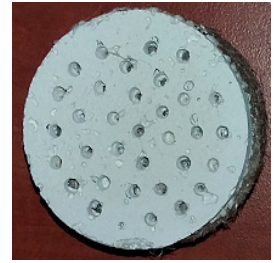

$S_{1}, d=3 \mathrm{~mm}, \mathrm{p}=7.5 \%$

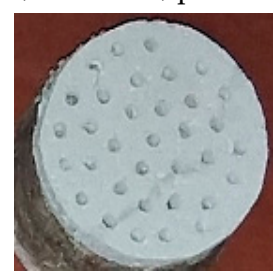

$\mathrm{S}_{2,} \mathrm{~d}=3 \mathrm{~mm}, \mathrm{p}=7.5 \%$

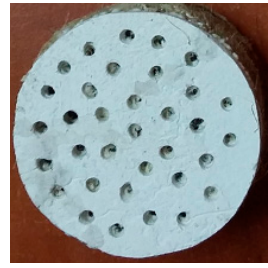

$\mathrm{S}_{3}, \mathrm{~d}=3 \mathrm{~mm}, \mathrm{p}=7.5 \%$

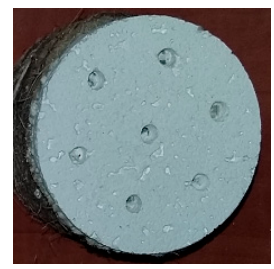

$\mathrm{S}_{1}, \mathrm{~d}=4 \mathrm{~mm}, \mathrm{p}=2.5 \%$

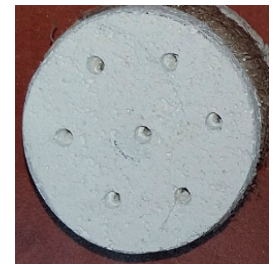

$\mathrm{S}_{2,} \mathrm{~d}=4 \mathrm{~mm}, \mathrm{p}=2.5 \%$

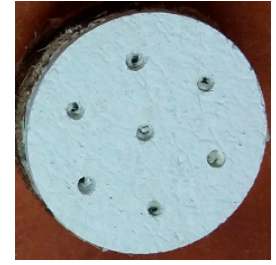

$\mathrm{S}_{3}, \mathrm{~d}=4 \mathrm{~mm}, \mathrm{p}=2.5 \%$

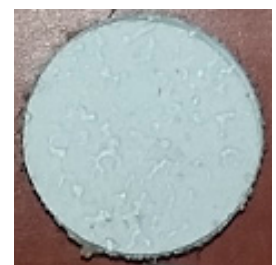

$\mathrm{S}_{1}$, unperforated

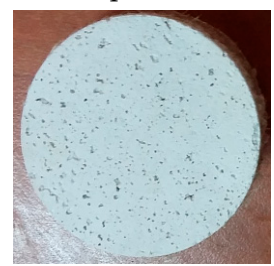

$\mathrm{S}_{2}$, unperforated

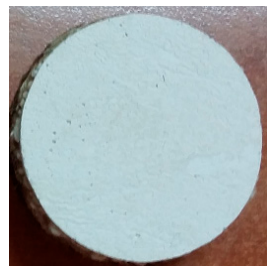

$S_{3}$, unperforated

Figure 2. Multi-layered composite samples $\left(\mathrm{S}_{1}, \mathrm{~S}_{2}, \mathrm{~S}_{3}\right)$ : unperforated and perforated with diameter sizes $\mathrm{d}=2 \mathrm{~mm}, 3 \mathrm{~mm}, 4 \mathrm{~mm}$ and perforation percentages $\mathrm{p}=2.5 \%, 5 \%, 7.5 \%$. 


\section{Results and Discussion}

\subsection{Mechanical Properties}

A comparison of the multi-layered panels' mechanical properties according to the perlite type was made in Table 2.

Table 2. Mechanical properties.

\begin{tabular}{|c|c|c|}
\hline Sample & $\begin{array}{c}\text { Compressive Strength } \\
\left(\mathrm{N} / \mathrm{mm}^{2}\right)\end{array}$ & $\begin{array}{c}\text { Bending Strength } \\
\left(\mathrm{N} / \mathrm{mm}^{2}\right)\end{array}$ \\
\hline $\mathrm{S}_{1}$ & 0.013 & 0.126 \\
\hline $\mathrm{S}_{2}$ & 0.011 & 0.171 \\
\hline $\mathrm{S}_{3}$ & 0.024 & 0.126 \\
\hline
\end{tabular}

It was observed that the compressive strength is related to density. The results showed that, for sample $S_{3}$ with increased density, the compressive strength value is higher because a denser material in a cross-section implies a decrease in voids and hence an increase in strength. Similar findings were made by Mosaberpanah and Eren [32] in their study on ultra-high-performance concrete, concluding that the increase in density leads to an increase in the compressive strength.

In the bending strength case, the results were influenced by the perlite granulometry. The sample $S_{2}$, which had a reduced granulometry, registered an increased bending value due to the smaller particle size of the perlite, which provided a good compaction characteristic of the material. In agreement, Castro et al. [33] stated in their study that the bending strength decreases in the case of bigger particles since the porosity between particles increases.

Generally, it was observed that the multi-layered composite panels present diminished compressive and bending strength values due to the reduced strength of the porous, expanded perlite aggregates, as reported in another study [34], where the silica sand was replaced by expanded perlite aggregates.

\subsection{Thermal Properties}

The thermal properties of the studied composites showed that the thermal conductivity coefficient values could be influenced by the perlite's density (Table 3).

Table 3. Thermal properties.

\begin{tabular}{cc}
\hline Sample & $\begin{array}{c}\text { Thermal Conductivity Coefficient } \\
\text { (W/mK) }\end{array}$ \\
\hline$S_{1}$ & 0.07257 \\
$S_{2}$ & 0.07377 \\
$S_{3}$ & 0.07098 \\
\hline
\end{tabular}

It may be noted that a decreased value was obtained for the sample in which perlite particles with increased density were used.

Thermal conductivity is a measure of how readily a material conducts heat. On the other hand, thermal insulation can be defined as the ability of a material to obstruct the flow of heat through its mass. If the thermal conductivity coefficient value of a material is low, it means that the material is a good thermal insulator.

In general, a higher density generates higher thermal conductivity values. Such results were reported by several researchers who investigated natural fibres (in the case of bamboo [35], rice straw [36], or jute fibres [37]). For some materials, an increase in density leads to decreasing values of thermal conductivity. This behaviour was observed for hemp [38], wheat straw [39], reed [40] and sheep wool [41]. This correlation could be explained in several ways. Pruteanu [39] states that the reduction in air volume within the material also reduces the rate of heat transfer through convection, resulting in lower 
thermal conductivity. Similar conclusions were drawn by Asdrubali et al. [40]. According to Ye et al. [41], either the structure of the material or the testing method could lead to this particular correlation.

The results obtained in this study can be related to the mentioned previous studies, although the increase in density was applied to the perlite grains instead of the plant fibres. In such conditions, it could be stated that the material structure plays an important role in governing the thermal conductivity coefficient.

The measured values were found comparable to those reported in the literature. The multi-layered panel, studied by Binici et al. [42], based on layers of sunflower stem and textile waste, had the lowest value of thermal conductivity of $0.0728 \mathrm{~W} / \mathrm{m} \cdot \mathrm{K}$. Furthermore, a composite panel studied by Efe and Alma [43], based on sunflower stalks pressed between two sheets of MDF boards, registered thermal conductivity values varying between 0.045 and $0.060 \mathrm{~W} / \mathrm{m} \cdot \mathrm{K}$ according to the method of determination.

\subsection{Acoustic Properties}

\subsubsection{Perlite Particle Size}

As shown in Figure 3, the variation in the perlite particle size changes the maximum values of the sound absorption coefficient and the position of the sound absorption peak, as follows:

- In the case of the rigid sheets made of "izo-pat $5 / 100$ " perlite $\left(\mathrm{S}_{1}\right)$, the maximum value of the sound absorption coefficient was 0.95 at $500 \mathrm{~Hz}$;

- Toward the lower frequencies, a maximum value of the sound absorption coefficient of 0.89 at $315 \mathrm{~Hz}$ was identified when the sheets were made of "120 mediu" perlite $\left(\mathrm{S}_{2}\right)$;

- In the "izo-pat 5/200"-based sheets $\left(\mathrm{S}_{3}\right)$, the position of the sound absorption coefficient peak was registered at $400 \mathrm{~Hz}$ having a maxim value of 0.84 .

Based on the obtained results, it was observed that a decrease in sound absorption values correlated with grain size reduction in the same density samples $\left(S_{1}\right.$ and $\left.S_{2}\right)$. Higher values of acoustic absorption were observed in the case of perlite with rough granulation $(0-5 \mathrm{~mm})$ composed of different grain sizes when compared with the perlite with fine granulation $(0-2 \mathrm{~mm})$. The results can be explained by the fact that in the case of the rigid sheets made with granules of different and larger sizes, the number of open voids connecting to the front face is higher. Furthermore, in their work, Marlof et al. [44] conclude that blending aggregates of different sizes results in a higher accessible porosity compared to the mixtures made using single-sized aggregates, resulting in an increased acoustic absorption in most cases.

For samples $S_{1}$ and $S_{3}$, with similar granulometry but different densities, a decrease in sound absorption values with increasing density was registered, a fact confirmed in the scientific literature [45].

The influence of particle size on acoustic absorption has been studied in several international works. In their study on loose expanded perlite, Garoum et al. [46] observed that for a given thickness, $\alpha_{\text {lexp }}$ decreases with grain size, and the first frequency resonance is shifted to lower values. Yamaguchi et al. [47] measured the sound absorption of porous mortar boards with different-sized fine-aggregate particles and target void ratios. The obtained results show that the first absorption coefficient peak shifts to a high-frequency band. The peak and dip values become greater by increasing the particle size of the fine aggregate and the void ratio. New composite materials were studied by Tiuc et al. [48], finding that the materials made of sawdust with a particle size greater than $4 \mathrm{~mm}$ had better sound absorption properties compared to the smaller particle size material.

The results found in the mentioned studies were also reflected in the proposed investigation, concluding that the granulation size variation and perlite density can have an important role in the acoustic absorption coefficient. 


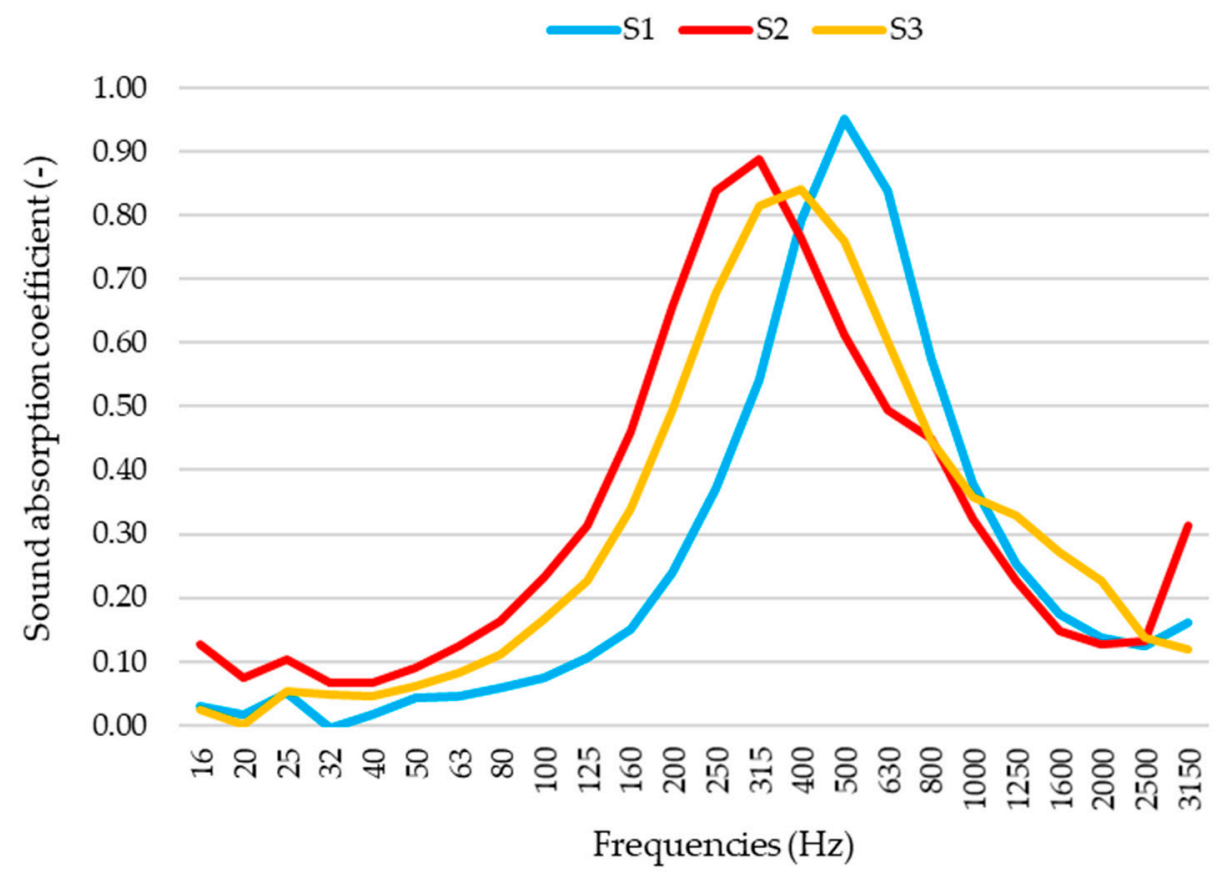

Figure 3. Sound absorption coefficient variation with perlite particle size (samples $S_{1}, S_{2}, S_{3}$ ).

\subsubsection{Perforation Diameter}

The influence of the perforation diameter on the acoustic absorption performance was studied by considering different hole sizes while keeping the same perforation percentages. Three perforation sizes were considered: 2,3 and $4 \mathrm{~mm}$ with $2.5 \%$ perforation. The holes were manufactured using drills. In Figures 4-6, a comparison between the perforated and unperforated samples is made.

Based on the obtained results, a correlation between the sound absorption coefficient values and the perforation size is observed. It can be concluded that:

- For "izo-pat $5 / 100$ " perlite samples $\left(\mathrm{S}_{1}\right)$, the peaks of the absorption coefficient present an increase in value and a shifted position to the right for the perforated surfaces. Specimens with 2 and $3 \mathrm{~mm}$ perforation sizes show an increase in the absorption coefficient peak to 0.98 at $630 \mathrm{~Hz}$, while the $4 \mathrm{~mm}$ perforation size registered a peak value of 0.96 at $630 \mathrm{~Hz}$;

- Similar results were registered in the "120 mediu" perlite samples $\left(\mathrm{S}_{2}\right)$, where the peak values of the sound absorption coefficient for 2 and $3 \mathrm{~mm}$ perforation sizes were 0.99 at $630 \mathrm{~Hz}$ and 0.95 at $500 \mathrm{~Hz}$, respectively, while for the $4 \mathrm{~mm}$ perforation size the peak value decreased to 0.79 for $500 \mathrm{~Hz}$ compared to the unperforated sample;

- In addition, an increase in the absorption coefficient peak with a movement to the higher frequencies was observed in the "izo-pat $5 / 200$ " sample case $\left(\mathrm{S}_{3}\right)$. A value of 1.00 for the $2 \mathrm{~mm}$ perforation size and 0.99 for the $3 \mathrm{~mm}$ perforation size was recorded for the frequency of $630 \mathrm{~Hz}$. Values identical with the unperforated sample were registered in the $4 \mathrm{~mm}$ perforation size sample case but with a shifted position to the $500 \mathrm{~Hz}$ frequency. 


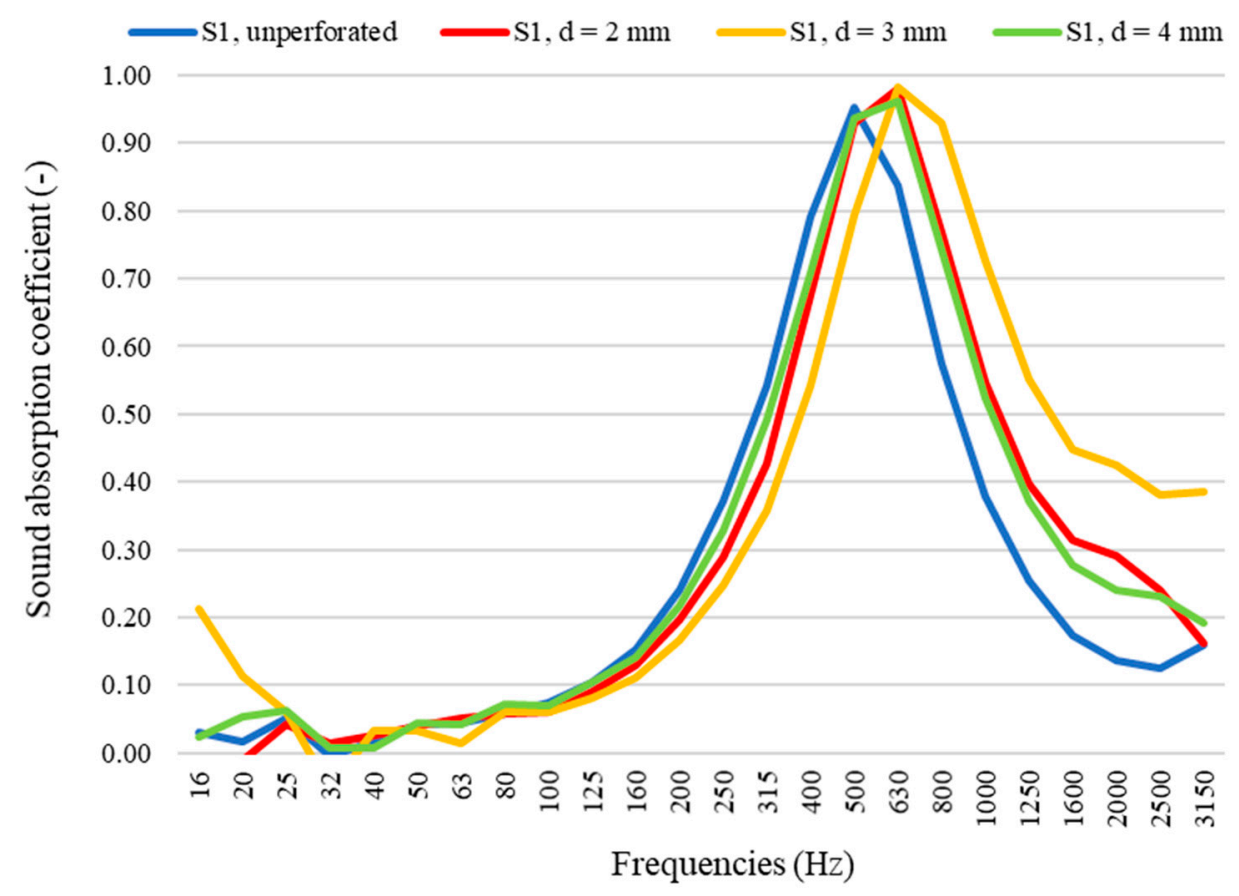

Figure 4. Sound absorption coefficient variation with different perforation diameters (sample $\mathrm{S}_{1}$ ).

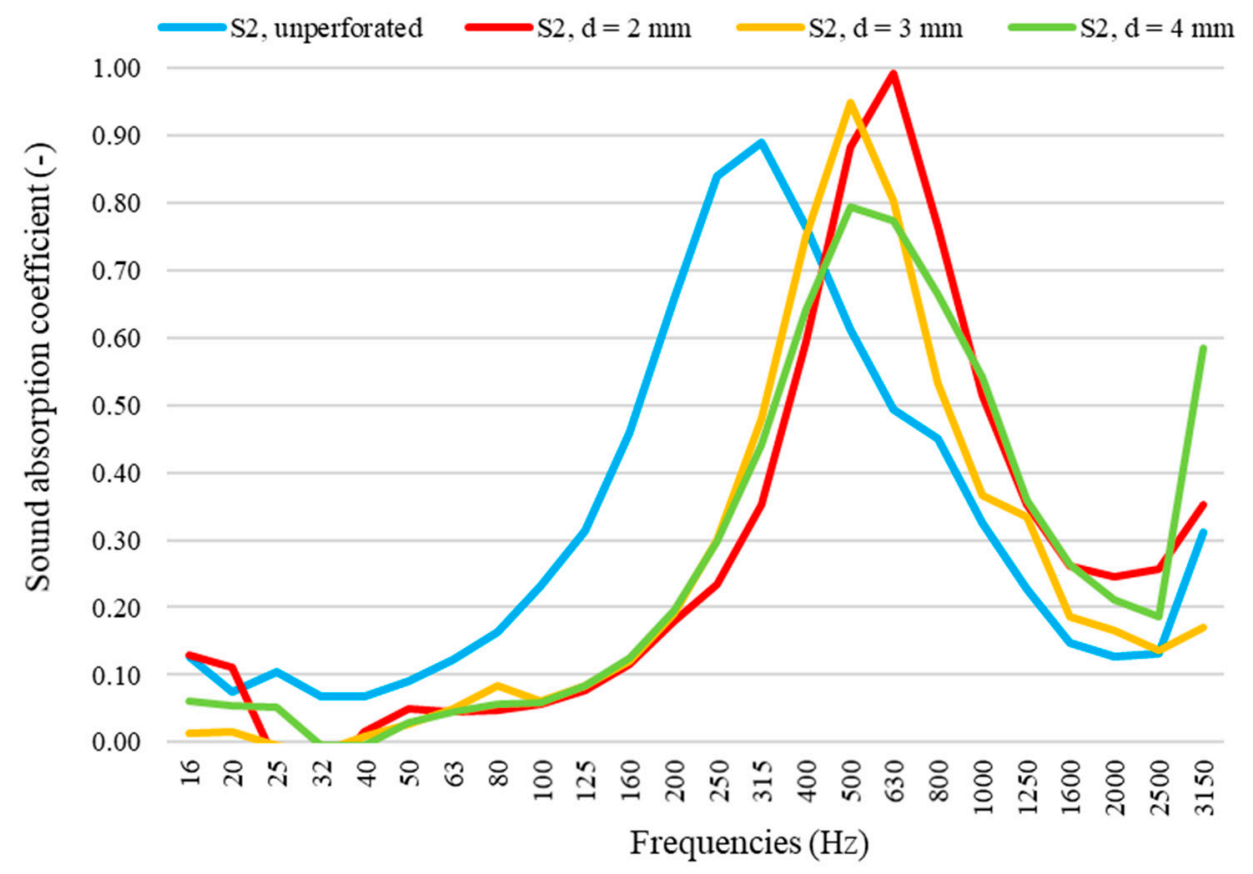

Figure 5. Sound absorption coefficient variation with different perforation diameters (sample $S_{2}$ ).

The increase in the perforation size can improve the acoustic absorption properties at higher frequencies, but as the hole diameter becomes larger the absorption registers a decrease. It can be concluded that this low absorptivity occurs due to the decrease in acoustic resistance caused by the larger perforation diameters [49].

In their study, Hamdan et al. [49] investigated the effect of perforation sizes on the membrane sound absorption performances, finding that the perforated membranes give better sound absorption coefficients and wider frequency ranges compared to the unperforated membranes. The influence of the perforation size on the acoustic absorption properties was studied by Tiuc et al. [50] in their research of some new, porous, soundabsorbing materials. The obtained results show that the perforation of the cork layer leads 
to an increase in the sound absorption coefficient compared to the non-perforated sample. Khrystoslavenko and Grubliauskas [51], in their research on the perforation's effect on sound insulation, concluded that a low percentage of perforation and lower hole diameters promote better sound absorption.

From the literature above and obtained results it can be observed that the perforation size can influence the absorption coefficient peak value and its position on the frequency range.

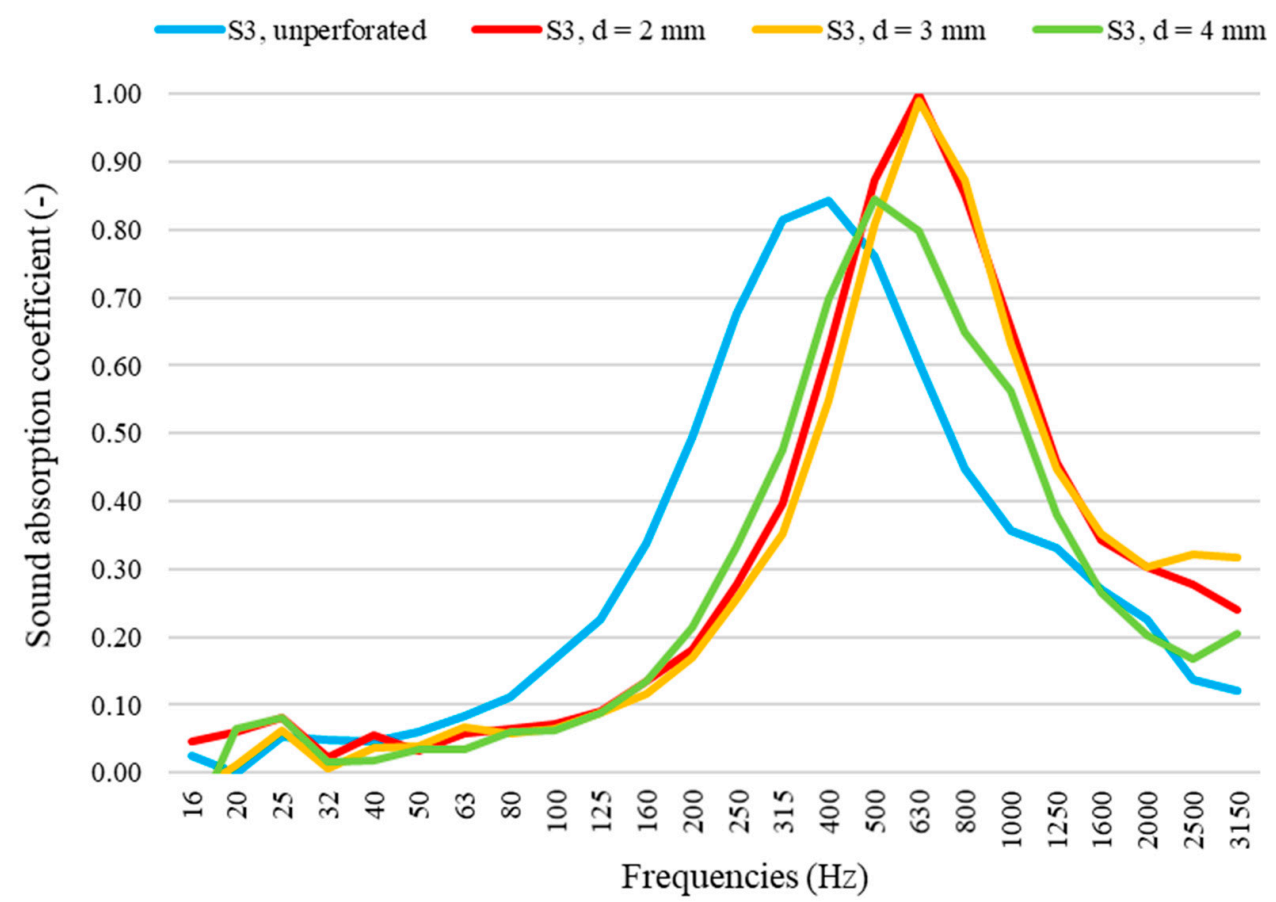

Figure 6. Sound absorption coefficient variation with different perforation diameters (sample $\mathrm{S}_{3}$ ).

\subsubsection{Perforation Percentage}

The influence of the perforation percentage was studied by measuring the acoustic performances of the obtained samples for three different perforation ratios: $2.5 \%, 5 \%$ and $7.5 \%$. The diameter of the perforations was set at $3 \mathrm{~mm}$. In Figures 7-9, the sound absorption coefficient curve for different perforated rates in comparison with the unperforated specimen is shown.

It can be concluded that the perforation rate can influence the acoustic absorption characteristics of the samples as follows:

- In the case of "izo-pat $5 / 100$ " samples $\left(\mathrm{S}_{1}\right)$ for different percentages, the peak of the sound absorption coefficient registered the following values- 0.98 at $630 \mathrm{~Hz}$ for $2.5 \%$, 0.99 and 0.97 at $800 \mathrm{~Hz}$ for $5 \%$ and $7.5 \%$, respectively;

- Similarly, for " 120 mediu" samples $\left(\mathrm{S}_{2}\right)$ whose percentages were $2.5 \%, 5 \%$ and $7.5 \%$, the peak of the sound absorption coefficient was 0.95 at $500 \mathrm{~Hz}, 0.98$ and 0.96 at $800 \mathrm{~Hz}$, respectively;

- For "izo-pat 5/200" samples $\left(\mathrm{S}_{3}\right)$, the maximum values of the sound absorption coefficient were 0.99 at $630 \mathrm{~Hz}, 0.99$ and 0.97 at $800 \mathrm{~Hz}$ for percentages of $2.5 \%, 5 \%$ and $7.5 \%$, respectively. 
$\longrightarrow \mathrm{S} 1$, unperforated $\longrightarrow \mathrm{S} 1, \mathrm{p}=2.5 \% \longrightarrow \mathrm{S} 1, \mathrm{p}=5 \% \longrightarrow \mathrm{S} 1, \mathrm{p}=7.5 \% \longrightarrow$ Flax, core material

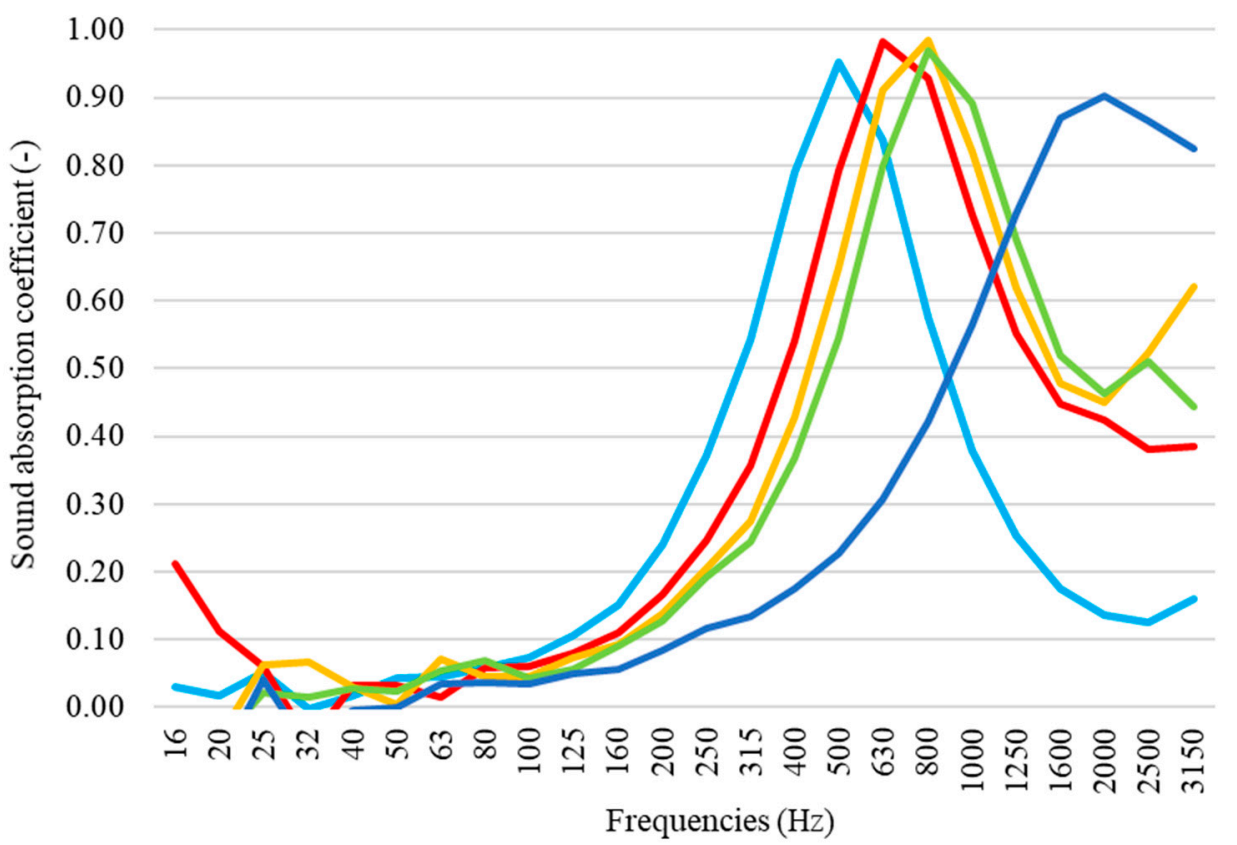

Figure 7. Sound absorption coefficient variation with different perforation percentages (sample $\mathrm{S}_{1}$ ).

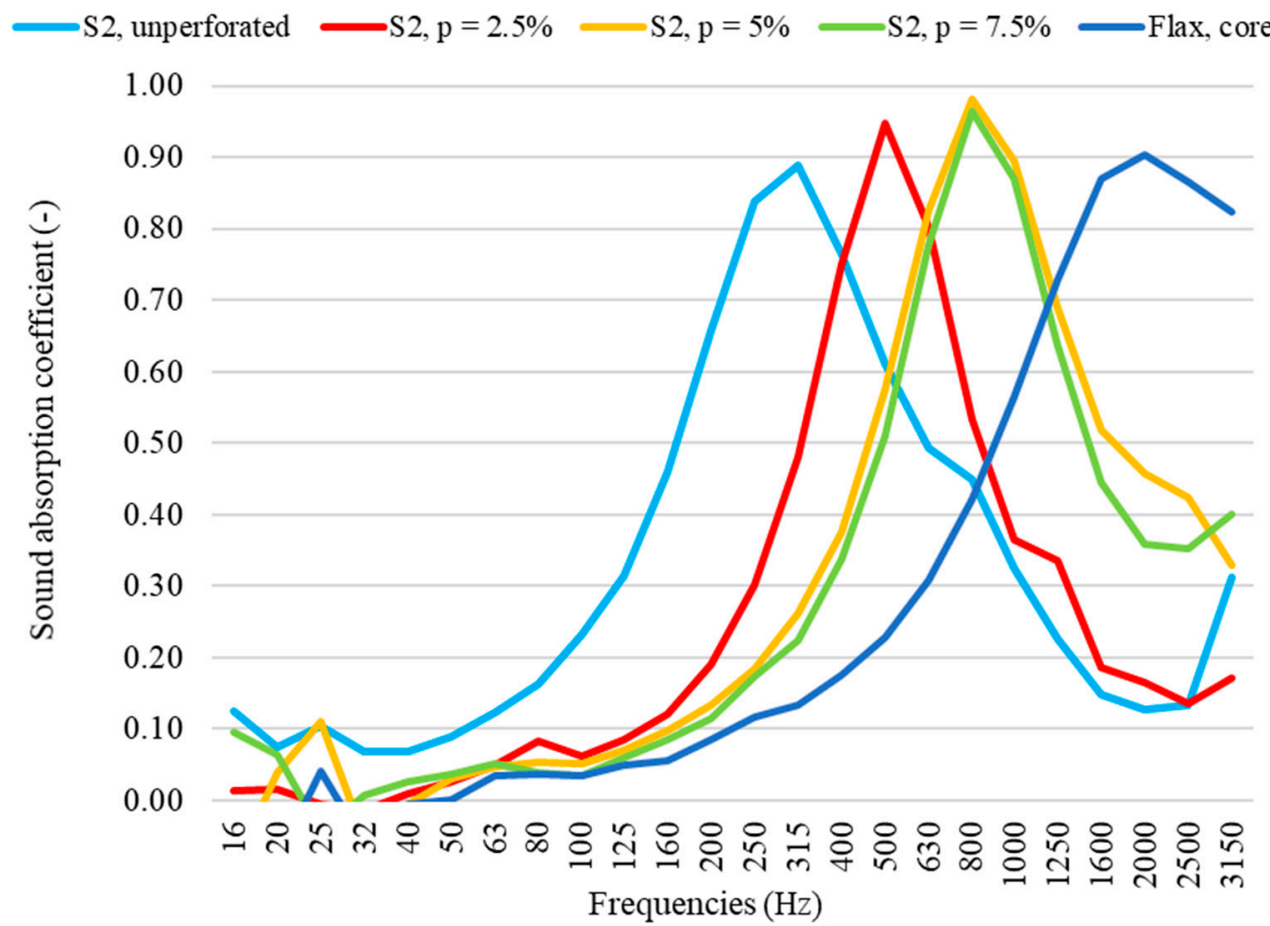

Figure 8. Sound absorption coefficient variation with different perforation percentages (sample $\mathrm{S}_{2}$ ).

Generally, it can be concluded that the acoustic absorption increases with the perforation rates of $2.5 \%$ and $5 \%$ and decreases for $7.5 \%$.

A displacement of the peak absorption coefficient to higher frequencies when the perforation ratio increases from $2.5 \%$ to $5 \%$ and stagnates as the ratio becomes $7.5 \%$ was observed. This is because in the $7.5 \%$ perforation rate case, the effect of the front face is reduced due to an increase in the number of holes, and the sound absorption coefficient curve tends to approach the flax fibre core material values. 
Furthermore, in their study of the sound absorption ability of screen or perforated membrane, Gai et al. [52] showed that the sound absorption peaks move to a high frequency with the increasing perforation rate. In their research, Peng et al. [53] observed that the increase in the perforation rate determined a decrease in the absorption peak and caused the location of the resonance frequency to move in the direction of a higher frequency.

Based on the obtained results and the above studies, it can be stated that the acoustic absorption properties of a material can be changed with the perforation rate.

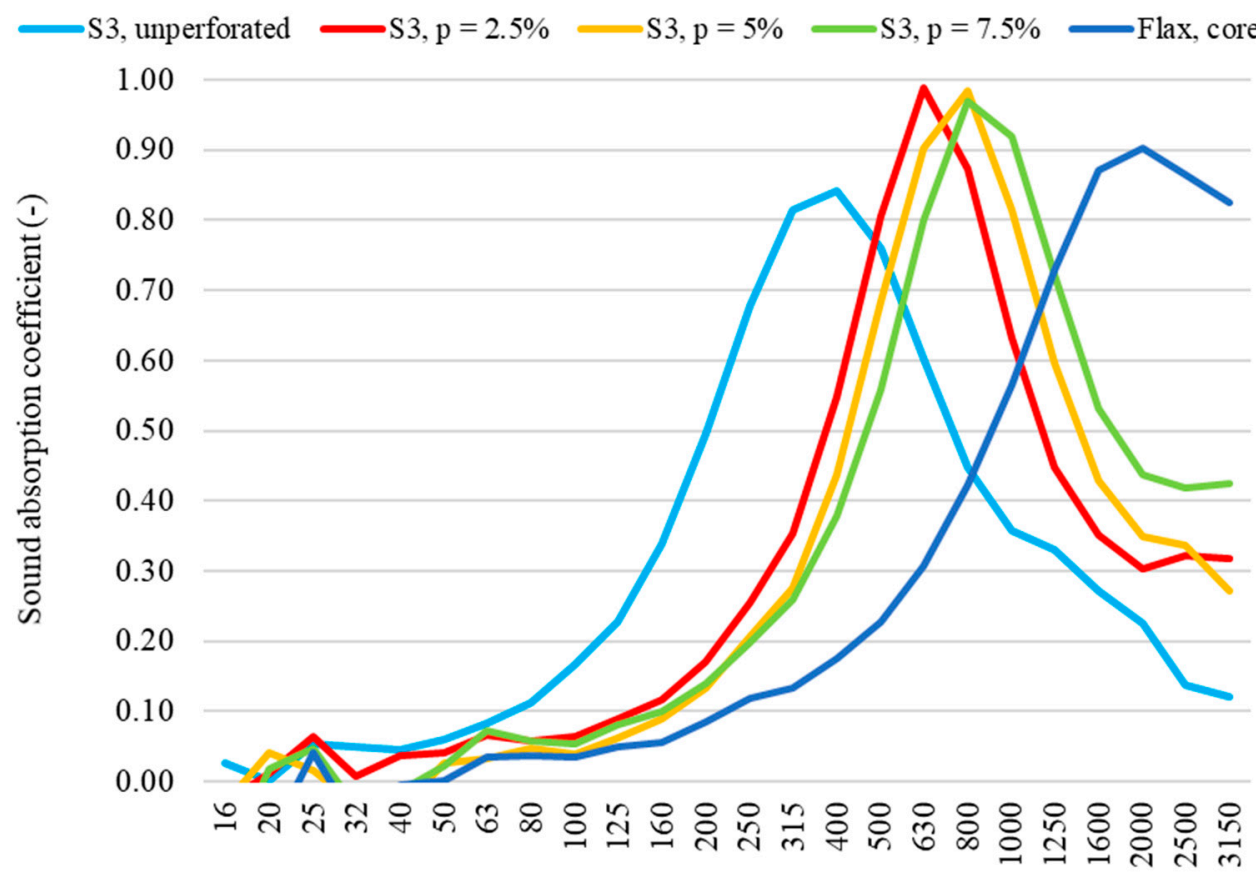

Frequencies $(\mathrm{Hz})$

Figure 9. Sound absorption coefficient variation with different perforation percentages (sample $S_{3}$ ).

\section{Conclusions}

New composite materials based on agricultural waste, with a positive economic and environmental impact, were developed for application in the construction sector.

The mechanical properties registered diminished values, an optimisation being important for future research. Furthermore, correlations between the compressive strength and density and between the bending strength and perlite granulometry were observed.

The thermal conductivity coefficient was measured. The obtained values showed that the perlite density could affect the thermal properties of the composite panels, resulting in the thermal conductivity coefficient being better for the sample that contains perlite with increased density.

Several acoustic determinations regarding the influence of the perlite particles' size, perforation diameter and perforation percentage on the sound absorption were made. The following conclusions were made:

- A decrease in sound absorption values with the grain size reduction for the samples with the same densities was registered. The maximum obtained value of the sound absorption was 0.95 at $500 \mathrm{~Hz}$ for the "izo-pat $5 / 100$ " perlite sample $\left(\mathrm{S}_{1}\right)$ and the minimum was 0.89 at $315 \mathrm{~Hz}$ for the "120 mediu" perlite sample $\left(\mathrm{S}_{2}\right)$;

- The acoustic absorption properties were better in perforated samples, but as the hole diameter increased, the absorption registered a decrease. The peaks of the absorption coefficient for the "izo-pat $5 / 100$ " perlite samples $\left(\mathrm{S}_{1}\right)$ increased in value to 0.98 at $630 \mathrm{~Hz}$ for 2 and $3 \mathrm{~mm}$ and decreased to 0.96 at $630 \mathrm{~Hz}$ for the $4 \mathrm{~mm}$ specimen. In the "120 mediu" perlite samples case $\left(\mathrm{S}_{2}\right)$, the peak value of the sound absorption 
coefficient for the $2 \mathrm{~mm}$ perforation size was 0.99 at $630 \mathrm{~Hz}$, for the $3 \mathrm{~mm} 0.95$ at $500 \mathrm{~Hz}$, while for the $4 \mathrm{~mm}$ perforation size was 0.79 at $500 \mathrm{~Hz}$. For the "izo-pat 5/200" perlite samples case $\left(\mathrm{S}_{3}\right)$, a peak value of 1.00 was obtained for the $2 \mathrm{~mm}$ perforation size and 0.99 for the $3 \mathrm{~mm}$ perforation size at the frequency of $630 \mathrm{~Hz}$. For the $4 \mathrm{~mm}$ perforation size, a value of 0.84 at $500 \mathrm{~Hz}$ was registered;

- An increase in the acoustic absorption performances when the perforation rate increased from $2.5 \%$ to $5 \%$ and a decrease for the $7.5 \%$ perforation rate situation were observed. The following values were registered-for the "izo-pat 5/100" samples $\left(\mathrm{S}_{1}\right)$, 0.98 at $630 \mathrm{~Hz}$, and 0.99 and 0.97 at $800 \mathrm{~Hz}$; for the "120 mediu" samples $\left(\mathrm{S}_{2}\right), 0.95$ at $500 \mathrm{~Hz}$, and 0.98 and 0.96 at $800 \mathrm{~Hz}$; for the "izo-pat 5/200" samples $\left(\mathrm{S}_{3}\right), 0.99$ at $630 \mathrm{~Hz}, 0.99$ and 0.97 at $800 \mathrm{~Hz}$ for percentages of $2.5 \%, 5 \%$ and $7.5 \%$, respectively.

The obtained results are very useful and can be used in the design of new innovative and sustainable solutions.

In the case of the studied samples, the perforations work as mechanical systems consisting of a hole with a length $\mathrm{l}$, a diameter $\mathrm{d}$ and a volume cavity $\mathrm{V}$, with the sound absorption being performed in a narrow frequency band.

Based on the actual research, an additional task to perform will be the increasing of the sound absorption capacity in a wide frequency band by using coupled resonators made of cavities of variable dimensions designed at different selective frequencies.

Author Contributions: Conceptualization, D.-R.T.-G. and R.I.; methodology and investigation, D.R.T.-G., R.I., A.E.T., T.-O.D., O.V. and H.C.; writing-original draft preparation, D.-R.T.-G.; revised the manuscript, D.-R.T.-G., R.I., A.E.T. and T.-O.D. All authors have read and agreed to the published version of the manuscript.

Funding: This research received no external funding.

Institutional Review Board Statement: Not applicable.

Informed Consent Statement: Not applicable.

Data Availability Statement: The data presented in this study are available on request from the corresponding author.

Conflicts of Interest: The authors R.I. and T.-O.D. are employees of MDPI. However they do not work for the Coatings Journal at the time of submission and publication.

\section{References}

1. Haghighat, F.; Kim, J.-J. Sustainable Built Environment—Volume I; EOLSS Publications: Paris, France, 2009.

2. Yıldızhan, S..; Çalık, A.; Özcanlı, M.; Serin, H. Bio-composite materials: A short review of recent trends, mechanical and chemical properties, and applications. Eur. Mech. Sci. 2018, 2, 83-91. [CrossRef]

3. Berardi, U.; Iannace, G. Acoustic characterization of natural fibers for sound absorption applications. Build. Environ. 2015, 94, 840-852. [CrossRef]

4. Carey, J.P. Handbook of Advances in Braided Composite Materials: Theory, Production, Testing and Applications; Woodhead Publishing: Cambridge, UK, 2016.

5. Barth, M.; Carus, M. Carbon Footprint and Sustainability of Different Natural Fibres for Biocomposites and Insulation Material: Study Providing Data for the Automotive and Insulation Industry; Nova-Institut GmbH: Hürth, Germany, 2015.

6. Joshi, S.V.; Drzal, L.T.; Mohanty, A.K.; Arora, S. Are natural fiber composites environmentally superior to glass fiber reinforced composites? Compos. Part A Appl. Sci. Manuf. 2004, 35, 371-376. [CrossRef]

7. Ali, M. Natural fibres as construction materials. J. Civ. Eng. Constr. Technol. 2012, 3, 80-89. [CrossRef]

8. Dashtizadeh, Z.; Khan, M.A.; Cardona, F.; Behmanesh, M.; Dashtizadeh, M. Mechanical and thermal properties of natural fibre based hybrid composites: A review. Pertanika J. Sci. Technol. 2017, 25, 1103-1122.

9. Vajje, S.; Krishna, N.R. Study on addition of the natural fibers into concrete. Int. J. Sci. Technol. Res. 2013, 2, $213-218$.

10. Rwawiire, S. Mechanical and Thermo-Acoustic Characterization of Barkcloth and Its Polymer Reinforced Composites; Technical University of Liberec: Liberc, Czech Republic, 2016.

11. Patnaik, A.; Mvubu, M.; Muniyasamy, S.; Botha, A.; Anandjiwala, R.D. Thermal and sound insulation materials from waste wool and recycled polyester fibers and their biodegradation studies. Energy Build. 2015, 92, 161-169. [CrossRef]

12. Zunaidi, N.H.; Tan, W.H.; Majid, M.S.A.; Lim, E.A. Effect of physical properties of natural fibre on the sound absorption coefficient. J. Phys. Conf. Ser. 2017, 908, 012023. [CrossRef] 
13. Brundtland, G. Our Common Future: Report of the 1987 World Commission on Environment and Development; United Nations: New York, NY, USA, 1987.

14. Arenas, J.; Crocker, M. Recent trends in porous sound-absorbing materials. Sound Vib. 2010, 44, 12-18.

15. Zach, J.; Korjenic, A.; Petránek, V.; Hroudová, J.; Bednar, T. Performance evaluation and research of alternative thermal insulations based on sheep wool. Energy Build. 2012, 49, 246-253. [CrossRef]

16. Xiao, B.; Huang, Q.; Chen, H.; Chen, X.; Long, G. A fractal model for capillary flow through a single tortuous capillary with roughened surfaces in fibrous porous media. Fractals 2021, 29, 2150017. [CrossRef]

17. Xiao, B.; Zhang, Y.; Wang, Y.; Jiang, G.; Liang, M.; Chen, X.; Long, G. A fractal model for Kozeny-Carman constant and dimensionless permeability of fibrous porous media with roughened surfaces. Fractals 2019, 27, 1950116. [CrossRef]

18. Prabhakaran, S.; Krishnaraj, V.; Zitoune, R. Sound and vibration damping properties of flax fiber reinforced composites. Procedia Eng. 2014, 97, 573-581. [CrossRef]

19. Fernandez, J.E. Flax fiber reinforced concrete-A natural fiber biocomposite for sustainable building materials. High Perform. Struct. Mater. 2002, 4, 193-207. [CrossRef]

20. Buksnowitz, C.; Adusumalli, R.; Pahler, A.; Sixta, H.; Gindl, W. Acoustical properties of Lyocell, hemp, and flax composites. J. Reinf. Plast. Compos. 2010, 29, 3149-3154. [CrossRef]

21. Zach, J.; Hroudová, J.; Korjenic, A. Environmentally efficient thermal and acoustic insulation based on natural and waste fibers. J. Chem. Technol. Biotechnol. 2016, 91, 2156-2161. [CrossRef]

22. Babenko, M.; Estokova, A.; Savytskyi, M.; Unčík, S. Study of thermal properties of lightweight insulation made of flax straw. Slovak J. Civ. Eng. 2018, 26, 9-14. [CrossRef]

23. Yang, W.D.; Li, Y. Sound absorption performance of natural fibers and their composites. Sci. China Technol. Sci. 2012, 55, 2278-2283. [CrossRef]

24. Council Directive 89/106/EEC of 21 December 1988 on the Approximation of Laws, Regulations and Administrative Provisions of the Member States Relating to Construction Products. Available online: https://eur-lex.europa.eu/legal-content/EN/TXT/ ?uri=CELEX:31989L0106 (accessed on 6 May 2021).

25. Tamas-Gavrea, D.-R.; Istoan, R.; Denes, T.-O.; Tiuc, A.-E. Conforul Acustic în Clădiri Administrative; Editura Risoprint: Cluj Napoca, Romania, 2020.

26. Kang, J. Acoustics and Sustainability: A Built Environment Perspective. Int. J. Acoust. Vib. 2020, 25. [CrossRef]

27. Tamas-Gavrea, D.-R.; Istoan, R.; Tiuc, A.E. Multilayered Composite Panel and the Method Used for Obtaining It. Patent OSIM RO133261, 30 April 2020.

28. SR EN 12089: 2013 Thermal Insulating Products for Building Applications_Determination of Bending Behaviour; Romanian Standards Association: Bucharest, Romania, 2013.

29. SR EN 826: 2013 Thermal Insulating Products for Building Applications_Determination of Compression Behaviour; Romanian Standards Association: Bucharest, Romania, 2013.

30. SR EN 12664: 2002 Thermal Performance of Building Materials and Products. Determination of Thermal Resistance by Means of Guarded Hot Plate and Heat Flow Meter Methods. Dry and Moist Products of Medium and Low Thermal Resistance; Romanian Standards Association: Bucharest, Romania, 2002.

31. SR EN ISO 10534-2: 2002 Acoustics-Determination of Sound Absorption Coefficient and Impedance in Impedances Tubes-Part 2: Transfer-Function Method (ISO 10534-2: 1998); Romanian Standards Association: Bucharest, Romania, 2002.

32. Mosaberpanah, M.; Eren, Ö. Effect of density on compressive strength of ultra high performance fiber reinforced concrete (UHPFRC) using design of experiment. Solid State Phenom. 2016, 249, 119-124. [CrossRef]

33. Castro, V.; Parchen, C.; Iwakiri, S. Particle sizes and wood/cement ratio effect on the production of vibro-compacted composites. Floresta Ambient. 2018, 25. [CrossRef]

34. Yildizel, S.A. Mechanical performance of glass fiber reinforced composites made with gypsum, expanded perlite, and silica sand. Rev. Română Mater. Rom. J. Mater. 2018, 48, 229-235.

35. Nguyen, D.M.; Grillet, A.-C.; Diep, T.M.H.; Bui, Q.B.; Woloszyn, M. Influence of thermo-pressing conditions on insulation materials from bamboo fibers and proteins based bone glue. Ind. Crops Prod. 2018, 111, 834-845. [CrossRef]

36. Wei, K.; Lv, C.; Chen, M.; Zhou, X.; Dai, Z.; Shen, D. Development and performance evaluation of a new thermal insulation material from rice straw using high frequency hot-pressing. Energy Build. 2015, 87, 116-122. [CrossRef]

37. Zakriya, G.M.; Ramakrishnan, G. Insulation and mechanical properties of jute and hollow conjugated polyester reinforced nonwoven composite. Energy Build. 2018, 158, 1544-1552. [CrossRef]

38. Bourdot, A.; Moussa, T.; Gacoin, A.; Maalouf, C.; Vazquez, P.; Thomachot-Schneider, C.; Bliard, C.; Merabtine, A.; Lachi, M.; Douzane, O.; et al. Characterization of a hemp-based agro-material: Influence of starch ratio and hemp shive size on physical, mechanical, and hygrothermal properties. Energy Build. 2017, 153, 501-512. [CrossRef]

39. Pruteanu, M. Investigations regarding the thermal conductivity of straw. Bul. Inst. Politeh. Din Iaşi. Secţia Constr. Arhit. 2010, 56, 9.

40. Asdrubali, F.; Bianchi, F.; Cotana, F.; D'Alessandro, F.; Pertosa, M.; Pisello, A.L.; Schiavoni, S. Experimental thermo-acoustic characterization of innovative common reed bio-based panels for building envelope. Build. Environ. 2016, 102, 217-229. [CrossRef]

41. Ye, Z.; Wells, C.M.; Carrington, C.G.; Hewitt, N.J. Thermal conductivity of wool and wool-hemp insulation. Int. J. Energy Res. 2006, 30, 37-49. [CrossRef] 
42. Binici, H.; Eken, M.; Dolaz, M.; Aksogan, O.; Kara, M. An environmentally friendly thermal insulation material from sunflower stalk, textile waste and stubble fibres. Constr. Build. Mater. 2014, 51, 24-33. [CrossRef]

43. Efe, F.T.; Alma, M.H. Investigating some physical properties of composite board, produced from sunflower stalks, designed horizontally. Ekoloji Derg. 2014, 23, 40-48. [CrossRef]

44. Marlof, A.; Neithalath, N.; Sell, E.; Wegner, K.; Weiss, W.J.; Olek, J. The influence of aggregate grading on the sound absorption of enhanced porosity concrete. Am. Concr. Inst. Mater. J. 2004, 101, 82-91.

45. Nandanwar, A.; Kiran, M.C.; Varadarajulu, K.C. Influence of density on sound absorption coefficient of fibre board. Open J. Acoust. 2017, 7, 1-9. [CrossRef]

46. Garoum, M.; Ayoub, B.; Said, B.; Abdelmajid, B.; Laaroussi, N. Investigation of sound absorption characteristics of loose and agglomerated perlite granulate. In Proceedings of the ICSV 2016-23rd International Congress on Sound and Vibration: From Ancient to Modern Acoustics, Athens, Greece, 10-14 July 2016; Volume 10-14.

47. Yamaguchi, M.; Tomiku, R.; Okamoto, N. Influence of particle size of fine aggregate and void ratio on sound absorption property of porous mortar. Cem. Sci. Concr. Technol. 2015, 69, 718-724. [CrossRef]

48. Tiuc, A.E.; Nemeş, O.; Vermeşan, H.; Toma, A.C. New sound absorbent composite materials based on sawdust and polyurethane foam. Compos. Part B Eng. 2019, 165, 120-130. [CrossRef]

49. Hamdan, N.I.; Zainulabidin, M.H.; Kasron, M.Z.; Ismail, A.E.; Kassim, A.S. Effect of perforation size on sound absorption characteristics of membrane absorber. Int. J. Integr. Eng. 2018, 10. [CrossRef]

50. Tiuc, A.E.; Rusu, T.; Vasile, O. The influence of perforations on the surface of a sound absorbing material on the sound absorption coefficient. Rom. J. Acoust. Vib. 2013, 10, 59-62.

51. Khrystoslavenko, O.; Grubliauskas, R. Theoretical and experimental evaluation of perforations effect on sound insulation. In Proceedings of the 10th International Conference on Environmental Engineering, ICEE, Vilnius, Lithuania, 27-28 April 2017; pp. 1-6.

52. Gai, X.L.; Li, X.H.; Zhang, B.; Xie, P.; Ma, Z.H. Modeling of perforated screens or membrane using rigid frame porous models combined with thin membrane resonance sound absorbing theory. Appl. Mech. Mater. 2013, 357, 1206-1211. [CrossRef]

53. Peng, L.; Liu, M.; Wang, D.; Song, B. Sound absorption properties of wooden perforated plates. Wood Res. 2018, 63, 559-572. 